\title{
Electronic Commerce Development Research in Sharing Economic Environment
}

\author{
Hong Zhou \\ Institute of Modern Logistics Industry \\ Beijing Wuzi University \\ Beijing, China \\ Zhongguancun Electronic Commerce and Modern Logistics \\ Industry Association \\ Beijing, China
}

\author{
Yan Miao \\ School of Information \\ Beijing Wuzi University \\ Beijing, China
}

\begin{abstract}
In recent years, China's e-commerce industry has rapid development, which drives the electronic commerce service enterprise arise. Sharing economy as a new business model and economic form under the age of internet provides extension, upgrade space for the further development of ecommerce. This article mainly combed and analyzed the basic theory about the development of the electronic commerce in sharing economic environment, and clarified that the sharing economic impact on development of electronic commerce.
\end{abstract}

Keywords-sharing economy; e-commerce; the theoretical study

\section{INTRODUCTION}

The financial crisis in capitalist countries broke out leading that the resident's income and purchasing power has fallen dramatically. People need to find new ways to increase revenue, feed their family life, so sharing economy was born. Traditional sharing economic subject and object just includes the supply, the demand and idle resource, which make information flow relatively slow. With the arrival of the era of Internet, the traditional sharing economic connotation and denotation have expanded. At present, sharing economic is not only a kind of business model mobilizing social resources and serving public consumption, but also is a macro economic and social hot issues about innovation of consumption concept, cultivation of new economic growth pattern, construction of economical society and the mass innovation entrepreneurship [1]. E-commerce as a product of internet development provides the advantageous guarantee for our country economy "new normal", and plays an important role in promoting transformation of traditional enterprise, promoting employment and entrepreneurship, stimulating domestic demand and transformation the way of consumption. From e-commerce infrastructure services enterprises regarding e-commerce platform as the core, extending to e-commerce technology service enterprises, ecommerce derivative services enterprises, electronic commerce gradually develops to the vertical and professional.

Hong Zhou-Vice President of the institute of modern logistics industry; Zhongguancun electronic commerce and modern logistics industry association deputy secretary-general.

Yan Miao-Master graduate student
Through fusing with sharing commerce, e-commerce gained more likely and space of development. In this paper, electronic commerce mode in sharing economic environment defines as follows: it is a transaction mode which guided by the internet thinking, relying on third-party diversified and convenient services platform, with large data, the internet of things, cloud computing, intelligent logistics technology as the carrier, will sale own idle advantage resources.

\section{RELATED THEORY OVERVIEW}

\section{A. Sharing Economy}

Sharing economy refers to an economic operation mode, using the third party information platform, transferring the right to use idle resources to the corresponding demanders, and reap the benefits.

The reason for the formation of sharing economic includes three aspects. Excess capacity and idle resources provides a based condition for the formation of sharing economic; the internet technology provides a supporting condition for sharing economy, setting up the third party trading platform, using big data, internet of things, cloud computing etc. information technology, making the supply and demand both sides match quickly the information you need, completing the transaction with high efficiency and low cost; Green consumption concept provides intrinsic motivation for sustainable development of sharing economic. As our country becomes more and more attention to resource saving and environment protection, all kinds of energysaving and innovation-oriented enterprises were founded and rapidly developed, consumer is no longer limited to traditional forms of trading, but pursuit more economical, individuation, human nature of consumption.

Sharing economy has its own unique characteristic: Based on the internet platform. Using the modern internet technology, building interactive platform, make information rapid, efficient flow, and providing a certain amount of credit guarantee; Participate in all. people is the core of sharing economy, sharing economic participants can be individuals, society, enterprises, organizations, union etc. organization form which can efficiently participate and share; The 
ownership relations. In sharing economy, people pursue is the use of value rather than the ownership, namely the ownership not transfer, use rights transfer for the moment. Resources form. In sharing economy, transferring resources include tangible or intangible form, has a wide range, such as houses, cars, knowledge, technology, time etc.

Sharing economic unique characteristics and background for widely using in every field laid a solid foundation. there are five kinds of typical business model: by focusing on new things happened around, then anywhere at any time in the form of novel Angle to share with the public, and this is twitter, namely weibo type; through the interest, the leisure, show off, sharing intimate and mood to life circle, this generates Facebook, WeChat, namely social type; through life-history and record, sharing feelings to the specific group, this accomplished Pinterest, mushroom street, namely strategy type; through technology, physical objects, services and other resources, providing resource share to demand of people, this generates Uber, taxi-hailing didi, namely resource type; Based on a particular area, sharing experience and feelings to the specific group, namely talent social hybrid type.

\section{B. E-commerce}

Generalized e-commerce refers to using various electronic tools to engage in business activities; Narrow ecommerce refers to accomplish trading activities and relevant service activities using the form of electronic trading in internet, intranet and value-added online, which is traditional e-commerce in each link electronic and networked. E-commerce mode refers to a basic way that the enterprise uses the internet to conduct business and obtains operating income, namely refers to business operation mode and profit mode based on a certain technical foundation in the network environment. At present, the common patterns for e-business are $\mathrm{B} 2 \mathrm{~B}, \mathrm{~B} 2 \mathrm{C}, \mathrm{C} 2 \mathrm{~B}, \mathrm{C} 2 \mathrm{C}$, etc.

B2C is first developed e-commerce business model in our country, mainly Online retail, its site types have mainly comprehensive shopping mall, vertical stores, department stores, online product customization, etc. on behalf of the enterprise are tmall, jingdong, dangdang. B2B model is the longest, the perfect business model in e-commerce developing, has many characteristics, such as purchase of low frequency and large amount of orders, can quickly bring profits and returns; its operation modes are mainly vertical B2B, level B2B, self-built B2B, etc., on behalf of the enterprise are alibaba, huicong net, business treasure website. $\mathrm{C} 2 \mathrm{~B}$ is released by the customer what you want, what is the price of the requirements for, and then by the merchants to decide whether to accept the customer's offer, its core is to aggregate scattered distribution but a large number of users to form a strong sourcing group, on behalf of the enterprise are U-deals, home property alliance. $\mathrm{C} 2 \mathrm{C}$ is between people and people of e-commerce, customers put the things in online sales, is the best electronic commerce business model to express the spirit of the internet and the advantage; number of users, commodity information and transaction number is more, using the flexible price mechanism, it provides a series of supporting services to buyers and sellers, on behalf of the enterprise are taobao, pat, ebay.

With the longitudinal and deep development of the ecommerce industry, e-commerce development model is also increasingly rich. New model and new field of e-commerce including crowdsourcing, $\mathrm{C} 2 \mathrm{~B}$ and recycling electronic commerce, etc. The crowdsourcing model such as everyone express, Quirky creative crowdsourcing, C2B model such as Mbaobao, IDX, Zbird, recycling electronic commerce such as tao green.

\section{E-COMMERCE MARKET IN SHARING ECONOMIC SUPPLY AND DEMAND SITUATION}

\section{A. Market Demand}

Market demand refers to that customers in a certain area, certain time, certain market marketing environment and market marketing plan is willing and able to purchase for amount of commodity or service, namely the sum of consumer demand. In 2015, China's e-commerce market size in sharing economic is about 1.956 trillion yuan, including 1.81 trillion yuan in turnover and 146 billion yuan to finance. What is expected to 2020, sharing economic scale will reach more than $10 \%$ of GDP. Classifications of customer requirements for e-commerce market in sharing economic environment are shown in "Fig. 1" below.

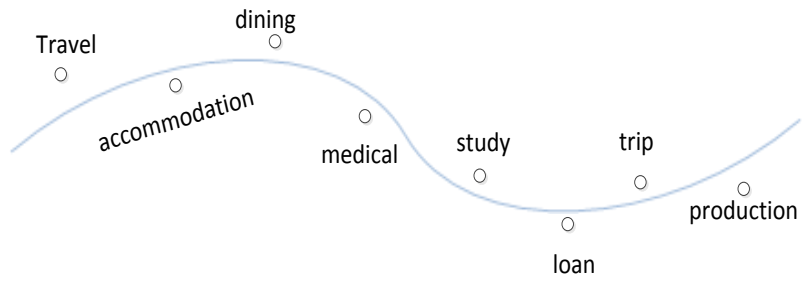

Fig. 1. Classification of customer requirements for e-commerce market in sharing economic environment.

In recent years, domestic electronic commerce scale in sharing economic environment has been expanding. Transportation and rental housing are first to enter electronic commerce development in sharing economic environment and are rapidly growing field, according to statistics, in 2015 volume of only travel field are more than RMB 50 billion by conservative estimates. According to the data of sutu research institute, the size of the market short rental online in 2012 started only 1.4 billion yuan, in 2014 reached 3.8 billion yuan, in 2015 reached more than 10 billion yuan and rose $163 \%$. Other electronic commerce field in sharing economy also gradually rise, size of the market for development potential is huge. In the medical field, the spring rain doctor so far gathered more than 92 million active users on the platform, has more than 410000 professional doctor which is public above Second Grade Hospitals; Famous doctor operation since launched in October 2015, a few months carried out thousands of operation and business monthly increase more than $40 \%$. In the field of network credit, souyidai was established in September 2014, revenue reached 6.5 billion yuan in 2015; P2P lending was established in May 2010, at present the registered users has 
reached 2.6 million and trading volume reached 16 billion yuan.

In the field of knowledge and science technology, Easy Science established internet platform about technology resources and scientific experiments, connoisseur to share knowledge have about 8000, and daily order reach 600 .

\section{B. Market Supply}

In 2015, China's e-commerce market in sharing economic environment mainly concentrated on financial, life service, transportation, production capacity, knowledge skills, house rent and other fields. About 50 million people participate in the service supply, which account for about $5.5 \%$ of the total workforce and the number of employee for the platform type enterprises have about 5 million people. At present, the economic form that e-commerce market in sharing economic environment involved in is shown in "Fig. 2".

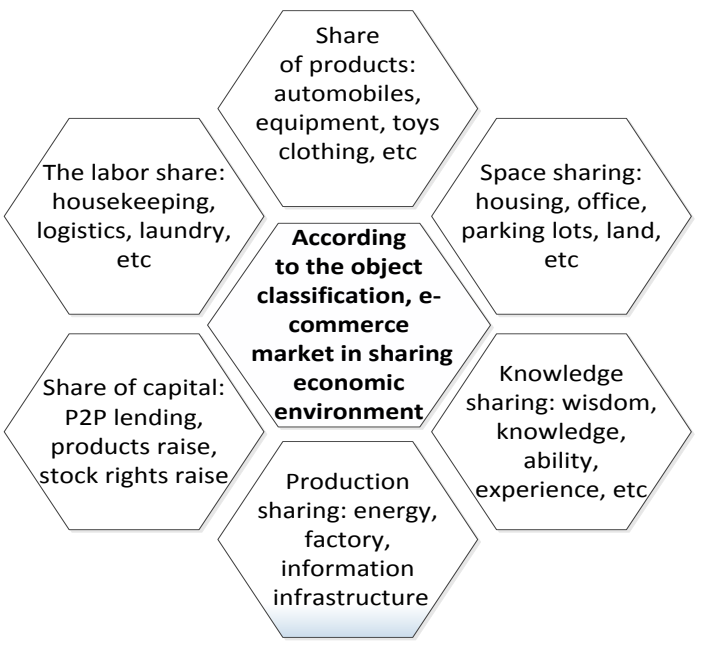

Fig. 2. The economic form classification about e-commerce market in sharing economic environment

Sharing economic forms for product, space, knowledge, money, etc. have been landed at the Chinese e-commerce market, which involving areas is relatively broad and provides guarantee to meet the different needs of customers. At the same time, the corresponding various sharing economic e-commerce platform and enterprise also gradually built, which provides enough market supply. On behalf of the enterprise were shown in "Table I".

TABLE I. REPRESENTATIVE ENTERPRISE OF ELECTRONIC COMMERCE IN SHARING ECONOMIC ENVIRONMENT

\begin{tabular}{|l|l|}
\hline Transportation & $\begin{array}{l}\text { Taxi-hailing didi, Dingding parking, EDAW car, PP } \\
\text { car rental }\end{array}$ \\
\hline Life service & $\begin{array}{l}\text { E bag wash, Meituan network, public comment } \\
\text { network }\end{array}$ \\
\hline Live & $\begin{array}{l}\text { Way home network, The pig short rent, The ant } \\
\text { short rent }\end{array}$ \\
\hline Finance & $\begin{array}{l}\text { P2P lender, Pleasant loan, Hongling venture capital, } \\
\text { Angel crunch, Product raise. }\end{array}$ \\
\hline $\begin{array}{l}\text { Knowledge and } \\
\text { skills }\end{array}$ & $\begin{array}{l}\text { Easy science, Good at, Baidu home, All design } \\
\text { network, Tao factory }\end{array}$ \\
\hline Medical & The spring rain doctor, Famous doctor operation \\
\hline Crowdsourcing & Jingdong to home, Everyone express, E-express. \\
\hline
\end{tabular}

\section{E-COMMERCE IN SHARING ECONOMIC SUPPORT SYSTEM}

\section{A. Policies and Regulations}

Industry development needs the support of policies and regulations from country to ensure the orderly and sustainable development in the economic market. In recent years, domestic e-commerce developed rapidly, in policy, relevant government departments issued a series of promoting policies, including overall plan of e-commerce development, the infrastructure construction of e-commerce, credit system construction, e-commerce applications, crossborder e-commerce, etc. which standardized to guide and promote the development of e-commerce industry.

Bulletin of the fifth plenary session of the party's 18 proposed "strengthen the support of flexible employment and new employment form", and the 13th Five-year Plan proposed "develop sharing economic and promote the syncretic development of the Internet and economic social", which has laid a good foundation for electronic commerce development in sharing economic environment. But sharing economy has not formed a clear legal norms and necessary industry standard system. Entering e-commerce industry is easily, and supervision of regulations is blank in the user's privacy and transaction security, which is easy to cause chaos of e-commerce in sharing economic.

\section{B. Credit System}

As the ministry of commerce enacted the e-commerce credit certification rules and integrity certification service provider belonging to derivative e-commerce service provider appeared, China's e-commerce credit certification system is gradually established, orderly competition of agencies form initially. Integrity certification service provider is based on the needs of e-commerce transactions, which overcame the credit obstacle and credit risk of ecommerce market; Their business is engaged in the ecommerce credit information collecting, sorting and processing, and provides related credit products and services, including e-commerce credit investigation, e-commerce credit rating, e-commerce credit services and management, etc.; It mainly solve the problem of information asymmetry in online transactions, reduce e-commerce transaction costs, reduce the economic loss of the repeated game and reduce the risk of bank credit. On behalf of the project and the enterprise are e-commerce credit management engineering star of credit plan, telecom CA security certification system of China, financial certification center of China, Beijing guofu'an E-commerce Security Certification Co. Ltd, "red shield 315" website. But there are still some questions that credit certification results are difficult to share, timeliness, lack of independent third parties, electronic commerce development in sharing economic environment is still facing the test of credit problems.

\section{Technical Support System}

Technology support system of electronic commerce in sharing economic environment is based on internet platform, supported by payment technology, software and hardware 
technology, used big data, internet of things, cloud computing technology to analyze and deal with, provided timely, quick, convenient and efficient technical support and information matching service for the supply and demand. Currently, the application of big data, internet of things and cloud computing is still in the early stages of development and still not mature, only a few large e-commerce companies are taking advantage of and research. The development of software and hardware technology system is relatively perfect, such as ufida, founder international, digital China company had stable leading and competitive position in this field. Electronic payment market scale is growing fast, such as alipay, Carla, WeChat pay, baidu wallet, etc. have been gradually accepted by people and companies.

\section{SHARING ECONOMIC IMPACT ON DEVELOPMENT OF ELECTRONIC COMMERCE IN OUR COUNTRY}

\section{A. Promote the Innovation of E-commerce Development Mode}

In recent years, in the field of electronic commerce, giants such as alibaba, jingdong continue to control the market share, then a large number of derivative e-commerce service enterprises has come. Enterprises and individuals having creative thinking are seeking breakthrough from a different Angle to obtain the dividend of the e-commerce market. Sharing economy with its unique characteristics expanded the intension and extension of the electronic commerce development, and offered a new economic model for the development of electronic commerce. The entrance of sharing economy mobilized fully idle resources and advantage resources in market, improved the elasticity and flexibility of supply, which can better adapt to the constantly changing consumer demand and make the electronic commerce that is not only a platform, but also a service, and use service to create value.

\section{B. To Promote the Sustainable Development of E- commerce}

Electronic commerce in sharing economic environment conforms to the national spirit of the "double innovation" and the policy of "resource conservation and environmental". Resource owners through the electronic commerce platform resell or sublet the old resources, which make the use value of old resources get promoted and reduce the resource environment pending costs, the life of people tend to be more green. Sharing economy has broken the traditional mode of hiring, fully mobilizes people's creativity and makes everyone work more flexible, full-time job is no longer the only source of income, professionals and part-time creator become new possibilities.

The development of e-commerce is no longer the pursuit of profit and economic growth in the short term, but the pursuit of long-term sustainable development, importantly, sharing economy created good conditions for this purpose.

\section{Promoting the Integration and Restructuring of Electronic Commerce Enterprise}

The entrance of e-commerce in sharing economic may change the current competitive landscape of e-commerce market development, speed up the integration and restructuring of electronic commerce enterprise. With the development of sharing economy, in the electronic commerce field, horizontal scalability is more and more big. In order to ensure its own enterprise occupies a place in the field of e-commerce, competition of e-commerce enterprise intensified with subdivision direction. In the future largescale e-commerce enterprises might be bigger and bigger, a few oligarchs around their core business and its electronic commerce vertical field build huge ecological system.

\section{CONCLUSION}

Sharing economy is also referred to peer-to-peer collaboration economy and collaborative consumption, which are social and economic ecological systems based on the share of people and material. It represents a more efficient mode of productivity and gradually penetrates into a niche for the development of electronic commerce. Individuals, enterprises, government should pay attention to this new e-commerce model potentially. At the same time, electronic commerce development in sharing economic environment is in a explored period, producing the phenomenon of "practice first, theory lag", namely related platforms develop rapidly, but support theory is less. Sharing economy and electronic commerce both separate theoretical research is relatively rich, so we should be combined with the both characteristics to speed up the theory research of ecommerce in sharing economic environment.

\section{REFERENCES}

[1] Zhang weifu, "Theory origin and applied dimension of sharing economic", Journal of nanjing university of finance and economics, 2015, pp. 9-12.

[2] Yang shupei, "the necessary conditions and sustainable development of China's sharing economic", Economic observer, 2015(13), pp.1618.

[3] Chang enjoy network, Five business model of "Sharing economy", http://www.vsharing.com/k/CIO/2015-8/713531.html, August 2015.

[4] Lv qianqian, Guo xiaoyan, Niuqing, "The comparison and analysis between mobile $\mathrm{O} 2 \mathrm{O}$ model and the traditional e-business mode", China business theory, 2015, pp. 59-62.

[5] A research group of state information center, "Sharing economy: global trend and overview of China - development report of chinese sharing economic (2016)", Zhejiang economy, 2016(6), pp.21-24.

[6] Fengjie, Sharing economic create new growing power - to visit "Internet +" national strategy think-tank experts, director and researcher of the China electronic commerce research center, Zhejiang economy, 2016(6), pp.28-29.

[7] Li yanling, Value creation pattern and influence of sharing economic, Business economy, 2015(10), pp.116-117. 